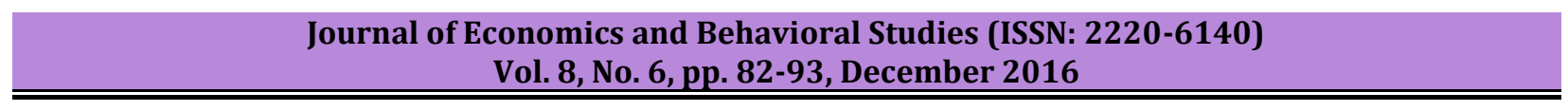

\title{
Academic Dishonesty: Prior perceptions and behaviour on cheating of Bachelor of Accountancy Freshmen at a Zimbabwean university
}

\author{
Togara Warinda \\ University of Zimbabwe, Zimbabwe \\ warindat67@gmail.com
}

\begin{abstract}
Academic dishonesty is a perennial problem the world over. Financial scandals that have rocked the world of business have refocused attention on the education of business students in general and accounting students in particular. Both accounting students and accountants have been found to have a low moral campus by some studies. The study examined the perceptions and behaviours on cheating of 61 accounting freshmen prior to any university instruction. Accounting freshmen had a remarkable understanding of what constituted cheating, and had indulged in one form of cheating or the other. Cheating behaviour varied with gender, religiosity, age and Advanced level points. The study recommends among other things staggering of courses within the examinations venue and universities coming up with clear policies on academic dishonesty and recycling of examinations.
\end{abstract}

Keywords: Academic dishonesty, cheating, cheating behaviour, accounting freshmen

\section{Introduction}

Academic dishonesty is a perennial problem in institutions of high learning the world over. Numerous studies have been carried out mostly in the developed countries probing various facets of this phenomenon. The focus of the studies has been among others been: why and how students engage in academic dishonesty; prevalence of academic dishonesty; strategies to curb the malice and so on. Academic dishonesty has implications on the evaluation of students' abilities at institutions of learning (Lupton et al., 2000; Michaels and Miethe, 1989). Lupton et al. (2002) argue that students who engage in academic dishonesty reduce their level of learning and ability to apply what they would have learnt. This problem is carried to societal level where there is a high probability that students who engaged in academic dishonesty continue with unethical practices at the workplace (Lawson, 2004; Nonis and Swift, 2001; Sims, 1993).

Unethical practices at places of work have resulted in financial scandals such as the Enron and demise of accounting firm Arthur Andersen. In 2003 it is estimated that fraudulent activities cost United States businesses about US $\$ 50$ billion per year (Coffin, 2003). According to the KPMG Africa Fraud Barometer (2012) the reported fraud in Zimbabwe for example in the last six months of 2011 was valued at US\$1, 2 billion. The same publication estimates fraud perpetrated by employees at $29 \%$ and management around $23 \%$ during the same period. On the job crimes or fraudulent activities cut across all sizes of businesses from the large corporations to small and medium sized businesses. The higher education system inputs its graduates into national systems that are also riddled with unethical practices such as fraud. Academic dishonesty thus becomes a major issue of concern not only to the institutions of higher learning and business but society at large (Klein et al., 2007; Adeniyi and Taiwo, 2011). It is submitted that academic dishonesty does not suddenly become an issue of concern at institutions of higher learning because a student has been admitted. Research has confirmed that academic dishonesty is quite high, in high school/secondary education (Cizek, 1997). Incidence of cheating which is a form of academic dishonesty has been found to increase with more years of schooling.

Most of the researches on academic dishonesty have been carried out in the developed countries with very little in the developing countries particularly on the African continent. Adeniyi and Taiwo (2011) noted that in Nigeria only about seven studies have been done on academic dishonesty. The lack of studies in the area does not necessarily show that all is well, but may be due to other factors. Henceforth the primary motivator for this study was to determine the extent to which accounting freshmen had academic dishonesty, particularly cheating ingrained in them prior to any university or college instruction. Some research has concluded that both accounting students and accountants have a lower moral reasoning ability than other professions or population groups (Armstrong, 1987; Lampe and Finn, 1992, 1994; Ponemon and Glazer, 1990; St Pierre et al., 1990). On the other hand other studies, for example Jeffrey (1993) did not attest to low 
moral reasoning of accounting students. Low moral reasoning ability has far reaching implications as far as ethical behaviour is concerned.

Understanding accounting freshmen's predisposition to academic dishonesty (particularly cheating) prior to university or college education will help faculty in ensuring an atmosphere that curbs the incidence of academic dishonesty is put in place. Secondly ethical behaviour of accountants has been attributed to socialisation within the accounting profession (Ponemon, 1992). However on admission, before any university instruction there is definitely very little or no socialisation at all to speak of on accounting freshmen. The study was therefore designed to get a snapshot picture of the perceptions and behaviour of accounting freshman towards cheating by answering the following research questions:

- How do freshmen define cheating?

- What are the perceptions of freshmen to cheating?

- How much had freshmen cheated prior to coming to university or college?

- Do age, gender, and advanced level points have an effect on freshmen's perceptions and behaviour on cheating?

- What is the effect of other factors such religiosity on freshmen's perceptions and behaviour on cheating?

From the above research questions the following objectives for the research were drawn:

- To ascertain freshmen's definition of cheating

- To establish freshmen's perceptions on cheating

- To find the extent of cheating behaviours of freshmen prior to university instruction

- To establish the degree to which age; gender; and advanced level points affected freshmen's perceptions and behaviour on cheating

- To evaluate the effect of religiosity on freshmen's perceptions and behaviour on cheating.

\section{Literature Review}

Academic dishonesty prevalent as it is, there is no agreed definition of what it is. There has been a tendency to use academic dishonesty interchangeably with academic misconduct (Oakley, 2011). In this study the two terms will be used synonymously. Academic dishonesty means different things to different people, in other words it is dependent on one's perspective (McCabe, 2005; McCabe and Trevino, 1993). Kibler et al. (1988:1) defined academic dishonesty as "forms of cheating and plagiarism which result in students giving or receiving unauthorised assistance in an academic exercise or giving credit for work which is not their own." Taylor et al. (2001:1) posit that academic dishonesty includes "cheating and plagiarism, the theft of ideas and other forms of intellectual property whether published or not." It is clear that the common thread that runs across the various definitions is that academic dishonesty consists of but is not limited to cheating and plagiarism. Another factor observed by Robertson (2008:16) on definitions of dishonest is that they describe "techniques for obtaining information in an unethical manner."

Michaels and Miethe (1989:870) defined cheating as the "fraudulent means of achieving scarce valued resources." They further assert that cheating is a learned behaviour. From a theoretical perspective it is not easy to define cheating concedes Oakley $(2011 ; 22)$. Brownwell $(1928: 764)$ was of the view that "being a cheater is something like being a criminal-it depends upon being caught." Plagiarism is defined by Oxford Concise Dictionary (1976) as taking and using another person's ideas as one's own. This includes thoughts, writings, and inventions and so on. Marsh (2007) further expounded on plagiarism by referring to it as literary theft. Advances in technology particularly the internet have resulted in the "cut and paste" type of plagiarism Scanlon (2006).

The lack of an agreed definition of academic dishonest or some of its forms like cheating has several implications. First and foremost this can increase the incidence of cheating among students because they may not perceive their actions as such (Partello, 1993; Rodabaugh, 1996). Students indeed see certain behaviours as not constituting cheating such as collaboration on assignments (Eskridge and Ames, 1993; Singhal, 1982). Institutions of higher learning should provide students with a definition of academic dishonesty (Karlins et al., 1988). For example in Zimbabwe, The Midlands State University Ordinance 2 subparagraph 1.2 expects students to have "a high level of personal integrity and development sense of responsibility towards others." 
The ordinance does not explicitly mention academic dishonesty or the several forms that it may take. Similarly the University of Zimbabwe Ordinance 30 has a similar clause word for word (paragraph 1.2). Oakley (2011:22) in a random check of what constituted academic dishonesty among some United States universities noted that "universities have not clearly or unanimously defined academic dishonesty or academic misconduct." It then follows that there is a great possibility that the many studies in the area were not necessarily measuring the same phenomena.

The weaknesses discussed above have not dissuaded researchers from probing other variables thought to have a bearing on academic dishonesty. One such variable has been the area of major at university or college. Of particular interest to this study are business students vis a vis other programmes more so because accounting falls into this broad classification (Oakley, 2011). Several studies have indicated a high prevalence of academic dishonest among business students compared to other disciplines (Cox, 2009; Meade, 1992; McCabe, Butterfield and Trevino, 2006; Bowers, 1964). For instance McCabe and Trevino (1995:209) in one of their studies noted that "one of the most discouraging findings in the student phase the research was that students who aspire to a career in business consistently reported the highest level of academic dishonesty." Contrary findings were reported by Iyer and Eastman (2006:108) who observed that "business students did not cheat more than did non business students." Their results were similar to those of Brown's study (1996). With respect to accounting students compared to other disciplines Brown and Saunders (1999:41) "did not find accounting majors to be more ethical than other business students." This finding resonates well with the conclusion drawn by Borkowski and Ugras's (1998) meta-analysis of 47 studies dealing with ethical behaviour of business students. They concluded that academic major had no effect on ethical behaviour.

Another interesting variable on academic dishonesty has been gender. There is no agreed position on the effect of gender on academic dishonesty. As early as 1957 Anderson concluded that female students were more moralistic and cheated less compared to their male counterparts. This has been confirmed in other studies were significant differences in ethical judgments were noted between genders (for example Ricklets, 1983; Beltramini et al., 1984; Al-Qaisy, 2008). On the other hand some studies have concluded that there is no significant difference between males and females as far as ethical behaviour and moral reasoning (Rest, 1986; McCuddy and Perry, 1996; Jones and Kavanagh, 1996). However of particular interest to this study are findings that tend to link accounting students and practitioners' ethical attitudes along gender. Ameen et al. (1996) found that female accounting majors were less tolerant than males of unethical behaviour a finding similar to that of Pierre et al. (1990). Upper echelons of accounting firms were found to exhibit lower levels of moral reasoning (Ponemon, 1990; Shaub, 1994). The management in these firms were predominantly male at 83\% (Shaub, 1994). Sweeney's study (1995) came up with results similar to those of Ponemon and Shaub above. Of particular interest in this study is whether there is this ethical predisposition in accounting freshmen along gender, more so given anecdotal evidence for example that whistle-blowers in the Enron and WorldCom were women (Sherron Watkins and Cynthia Cooper respectively).

Age has also been found to have an effect on ethical attitudes/behaviour. Borkowski and Ugras (1998) in their meta-analysis of 47 studies found that students became more ethical with age. Kohlberg (1981) in his theory of moral development posits that individuals mature morally in the course of life, ceteris paribus. Indeed there is a growing body of research that suggest that young college students cheat more than older and more mature students (Baird, 1980; Franklyn-Stokes and Newstead, 1995; McCabe and Trevino, 1997). In addition to age Whitley (1998) found that younger and unmarried students cheat more compared to older and married students. In Zimbabwe the normal age to start grade one is 7 years and one should enter university at around 20 years and thus accounting freshmen are relatively young adults. On the extreme Michaels and Miethe found older students more likely to cheat compared to younger ones. Bennet (in Wilkinson and Pickett, 2009) contends that demographic variables such as age, gender education, etc. do not have an effect on academic dishonesty but rather attitudinal characteristics such peer influences, ethical positions and their interrelationship. However it would seem more empirical researches to date resonate well with the theory that ethical behaviour is affected by age among other variables.

According to CIA World Factbook (2011) the religious make up of Zimbabwe is 50\% syncretic; 25\% Christian; 24 indigenous; and 1\% Muslim and other religions. Kohlberg (1981:336) defines religion as "...a conscious response to, and an expression of the quest for the ultimate meaning for moral judging and acting. As such the 
main function of religion is ... to support moral judgment and action as purposeful human activities." Religiosity is generally associated with higher ethical attitudes especially with regard to student cheating (Allmon et al., 2000: Barnett et al., 1996). In their study Conroy and Emerson (2004:361) concluded that" religiosity is significantly correlated with ethical perceptions." By definition religiosity is a person's degree of religious commitment or devotion ((Peacock and Poloma, 1998; Koenig et al., 1997). Koenig et al. (1997) came up with three dimensions or religiosity: organisational, non-organisational and intrinsic. This study is particularly interested in non- organisational religiosity that is the amount of time spent in private religious activities such as prayer and meditation (Rowatt and Kirkpatrick, 2002). Finally academic performance as far as it influences academic dishonesty is now explored. Klein et al. (2007) noted that "the lower the GPA (grade point average) and the younger the student, the higher the level of cheating." This finding is consistent with other similar studies done (Crown and Spiller, 1998; Whitley, 1998; Kerkvliet and Sigmund, 1999; Zastro, 1970). Even earlier studies have associated academic dishonesty with low intelligence of the student (Brownell, 1928; Hettherington and Feldman, 1964; Johnson and Gormly, 1972). The minimum entry requirements into the Bachelor of Accountancy Honours at the Zimbabwean university where this study was carried out is two advanced level passes among other things. Stiff competition over the years has meant that only students with the highest ' $\mathrm{A}$ ' level points are admitted into the programme. As part of efforts to address the gender disparities female students with lesser points than male students are taken. It follows that the accounting programme takes some of the best academic performers at ' $A$ ' level.

\section{The present study}

A questionnaire was administered to accounting freshmen during the first semester at the university in 2013. The instrument was administered during the period of student registration prior to the commencement of lectures. This was before the introduction of online registration. Registration is done by the Chairpersons of departments and other lecturers. The researcher being a member of the faculty personally administered the questionnaire to accounting freshmen who registered when the researcher was on duty. The registration duty rooster is drawn up by the chairperson and no particular criteria are followed on who should be registering and on what particular day. Henceforth the researcher had no influence whatsoever on those who registered on this particular day.

The questionnaire used items adapted from a similar study by Klein et al. (2007). Nine of the items were from Klein et al. study and the tenth was put by the research probing a common phenomenon in free sitting tests and exercises observed over the years. Houston (1986) found that answer copying is related to the degree of acquaintanceship among students. The first section sought to ascertain students' perceptions of what constituted cheating using three possible responses:

- Cheating

- Trivial cheating

- Not cheating

The next section was probing the frequency with which students may have indulged in any of the ten behaviours. This was based a nominal scale with only two possible responses either "I have done this" or "I have not done this". Finally the last section was on demographic variables and covered:

- Age

- Gender

- Religion

- Non-organisational religiosity

- Advanced level points

Students were guaranteed of anonymity and were given the questionnaire to complete during the time they were waiting for faculty to do the registration formalities. Sixty one questionnaires were administered on the specific day and were all returned. Only two questionnaires were unusable. The sixty-one freshmen who took part in the survey represented about $33 \%$ of the full time freshmen admitted to the Bachelor of Accountancy programme during the that academic year. 


\section{Results}

The average age of the respondents was 19.44 years within the age range of 18 to 23 years. Seventy one percent of the respondents were aged 19 and 20 years. Out of the 59 respondents 24 were males, 33 were females and 2 did not indicate their gender. Interestingly all respondents professed to be Christians. In terms of academic performance, 25 had 15 Advanced Level points (42.4\%) and the remainder 14 points (34 students). A further analysis showed that 9 females (36\%) had 15 points and a $15(47 \%)$ had 14 points. On the other hand male freshmen with 15 points were $16(64 \%)$, and $17(53 \%)$ had 14 points. While the possibility of students indicating better passes could not be ruled out the passes were generally in sync with the academic profiles of students admitted into the programme that year.

Perceptions of cheating: Ninety three percent of the students considered "Copying another student's homework or assignments" as cheating. On a scale ' 3 is Cheating', ' 2 is Trivial cheating', and ' 1 is not cheating' the mean score was 2.93 with a standard deviation of 0.254 . This was the highest mean for all the ten statements and also with the smallest standard deviation thus showing that there was a high degree of agreement on what constituted cheating as far as the statement was concerned. The results are similar to the mean of 1.63 obtained in Klein et al.'s study (2007) Sitting close to a friend during examinations was not considered as cheating by $66 \%$ of the respondents (mean 1.47 and standard deviation 0.728 ). The implication of this is that this may increase cheating more so because students do not perceive such as cheating (Partello, 1993; Rodabaugh, 1996).There is more likelihood that students who prefer to sit close together during examinations have an ulterior motive, that of collaborating one way or the other which is also cheating. Sitting arrangements or space is a situational factor that may affect cheating behaviour as noted by Houston (1986) who argues that students appear to cheat more in large and crowded classrooms. It would seem that students have a good understanding of what constitutes cheating in 6 out of the 10 statements with means between 2.80 and 2.93 and standard deviations between 0.254 and 0.581 . Results of the perceptions are shown in Table 1.

Table 1: Students' perceptions: What constitutes cheating? (Means- 3 cheating, 2 trivial cheating, 1 not cheating)

\begin{tabular}{|c|c|c|}
\hline Statement & $\operatorname{Mean}(n=59)$ & $\begin{array}{l}\text { Standard } \\
\text { deviation }\end{array}$ \\
\hline 1. Copying another student's homework or assignments & 2.93 & 0.254 \\
\hline 2. Allowing another student to copy your homework or assignments & 2.66 & 0.633 \\
\hline 3. Collaborating on assignments you are supposed to do alone & 2.66 & 0.685 \\
\hline $\begin{array}{l}\text { 4. Taking notes and other materials not allowed into the examination } \\
\text { venue }\end{array}$ & 2.90 & 0.443 \\
\hline $\begin{array}{l}\text { 5. Looking or copying from someone else's examination answers during a } \\
\text { test }\end{array}$ & 2.90 & 0.402 \\
\hline $\begin{array}{l}\text { 6. Allowing someone else to copy from your examination answers during a } \\
\text { test }\end{array}$ & 2.80 & 0.581 \\
\hline 7. Finding out what is on an examination before taking it & 2.81 & 0.572 \\
\hline 8. Telling another student what is on the examination before taking it & 2.64 & 0.713 \\
\hline $\begin{array}{l}\text { 9. Programming extra help or information into a calculator, cell phone or } \\
\text { some other device that you then use in an examination }\end{array}$ & 2.85 & 0.519 \\
\hline 10. Sitting close to a friend during examinations & 1.47 & 0.728 \\
\hline
\end{tabular}

Cross tabulations were also done to further analyse perceptions of students on what constitutes teaching. Chisquare testing was not done since the sample size was less than 100 . As a rule of the thumb Chi-square tests are more useful with sample sizes of 100 and above. Fisher's Exact Test would have been the next best alternative but was not going to provide more useful results since the research was interested in getting an overview on entry, without delving much into the variables in the study. To this end therefore a relative analysis was done based on the number that perceived a statement as outright cheating. Male students had a relatively relaxed view on statements $4,6,7,8,9$ and 10 (Table 1) compared to female students. It can thus be inferred that a relaxed view on cheating may actual increase the propensity of the male students to indulge in the same. Females on the other hand were relaxed on statements 1,2, and 5. There was no gender based 
difference on what constitutes, cheating on statement number 3 . The results on gender seem to agree with previous studies that seem to suggest that males cheat more than females (Ford and Richardson, 1994).

Those students with 14 points at Advanced Level had a relaxed view of cheating on statements 1 to 5 and 9 . On statement 6 there was no difference in perception between freshmen with 15 and 14 points. Freshmen with 15 points were more tolerant in their definition of cheating on statements 8,9 and 10 . This finding is consistent with other studies for example, Crown and Spiller (1998) who found that students with relatively lower grade point averages cheat more (see also Klein et al., 2007). It was also noted that freshmen aged 21 to 23 years were consistent in defining statements 1,4,5,6 and 9 as outright cheating compared to the 18 and 19 years age group (88.1\%). Age in earlier studies is also a factor that has a bearing on cheating, the young the student the higher the level of cheating (Crown and Spiller, 1998; Whitely, 1998; Klein et al., 2007). Freshmen aged 18 years perceived statements 4 and 5 as outright cheating like the 21,22, and 23years age groups. There was no clear pattern on the rest of the statements between the various age groups. Students who prayed once a week perceived statements 1 to 5 and 7 as outright cheating. This was followed by those who prayed more than once a week with statements 1, 3 and 4 considered as outright cheating. Interesting enough freshmen who claimed to pray daily only, out did the other groups on statement 6, 9 and 10.

Frequency of cheating: About 51\% of freshmen had allowed another student to copy homework or assignments (Mean 3.49 and Standard deviation 0.504).Similarly, Klein et al. (2007) in their study 51.5\% students had allowed another student to copy homework or assignments. Trailing next was collaborating on individual assignments with $44.1 \%$ and a mean of 3.49 and standard deviation at 0.504 .Students often do not feel that collaborating on assignments is cheating (McCabe and Cole, 1995). A further $40.7 \%$ had sat close to a friend during examinations (Mean 3.59 and Standard deviation 0.495). Freshmen (30.5\%) admitted to copying another student's homework or assignments (Mean 3.69 and Standard deviation 0.464).Behaviours least indulged in by freshmen were statements 4, 5,7and 9 (Table 2).Lin, et al., (2006) found freshmen to have more academically dishonesty behaviours in the above behaviours save for that on sitting close to a friend. The results are more telling of the fact that freshmen come to university with cheating behaviours already ingrained in them.

Students aged 21 and above reported not to have indulged in cheating forms, statement 4, 7, 8 and 9 . The 19 and 20 years age group representing $71.1 \%$ of the sample admitted to allowing another student to copy their homework or assignments ( $60 \%$ and $50 \%$ respectively). Between these two age groups the 19 years group had the highest percentage of cheating behaviour on statements 2,3,4,5,7,8,9 and 10 which seems to confirm earlier researches younger students cheat more compared to older students (Baird, 1980). Comparing the 18 years age group to the 19 year age group, the young freshmen appeared to have cheated less on statement $1,2,3,8$ and 10 .

Table 2: Students' cheating behaviour ( $3=\mathrm{I}$ have done this; 4=I have not done this)

\begin{tabular}{|c|c|c|}
\hline Statement & $\operatorname{Mean}(n=59)$ & $\begin{array}{l}\text { Standard } \\
\text { deviation }\end{array}$ \\
\hline 1. Copying another student's homework or assignments & 3.69 & 0.464 \\
\hline 2. Allowing another student to copy your homework or assignments & 3.49 & 0.504 \\
\hline 3. Collaborating on assignments you are supposed to do alone & 3.56 & 0.501 \\
\hline $\begin{array}{l}\text { 4. Taking notes and other materials not allowed into the examination } \\
\text { venue }\end{array}$ & 3.95 & 0.222 \\
\hline $\begin{array}{l}\text { 5. Looking or copying from someone else's examination answers during } \\
\text { a test }\end{array}$ & 3.95 & 0.222 \\
\hline $\begin{array}{l}\text { 6. Allowing someone else to copy from your examination answers } \\
\text { during a test }\end{array}$ & 3.93 & 0.254 \\
\hline 7. Finding out what is on an examination before taking it & 3.95 & 0.222 \\
\hline 8. Telling another student what is on the examination before taking it & 3.90 & 0.305 \\
\hline $\begin{array}{l}\text { 9. Programming extra help or information into a calculator, cell phone } \\
\text { or some other device that you then use in an examination }\end{array}$ & 3.95 & 0.222 \\
\hline 10. Sitting close to a friend during examinations & 3.95 & 0.495 \\
\hline
\end{tabular}


Cross tabulation of cheating behaviour against Advanced Level points shows that 14 pointers admitted to cheating more than those with 15 points on statements $2,3,4,5,6,7,9$ and 10 . This seems to confirm earlier research findings that students with lower grade point averages are more likely to cheat (Crown and Spiller, 1998). Freshmen with 15 points had copied another student's homework or assignments and told others what was on the examination more times compared to those with 14 points. Significant differences between these two groups were on statement number 3 where $50 \%$ of students with 14 points had collaborated on individual assignments compared to those with 15 points at $36 \%$. This was followed by statement 1 where $36 \%$ of freshmen with 15 points had cheated compared to the other group with $26 \%$. The question is how reflective are high school results of the actual academic ability of students within the Zimbabwean context.

Male freshmen reported cheating more times compared to females on statements 1, 3, 4, 5, 6, 7, and 9 which behaviour is consistent with earlier studies (Baird, 1980) Female students had cheated more than males on statements 2, 8 and 10. Fifty eight percent of the female respondents had allowed another student to copy their homework or assignments (males, 48\%). While more male freshmen had collaborated on individual assignments and more females had sat close to friends during examinations the differences are not great (collaborating males $45 \%$, females,42\%; sitting close males $39 \%$, females $42 \%$ ). Nine percent of the males reported programming extra help (statement 9); copying someone during a test; and finding what is on the examination before taking it, behaviours which none of females had indulged in.

Freshmen who prayed daily cheated more than the other groups on statements 1 and 3 (34\% and 49\% respectively). The group that prayed once a week were at their worst in relation to the other groups on statements 5, 8 and 9 (14\%, 29\% and 29\% respectively). Those who prayed more than once a week but not daily had not indulged in cheating behaviours in statements $3,5,6,7,8$, and 9 , and were the worst cheaters on statements 2 and 4 only. Students who prayed once a week had not taken prohibited materials into the examination venue, neither had they allowed someone to copy their examination answers nor finding what is on the examination before taking it. Interesting enough the group that reported praying daily had partaken in all the ten behaviours. There was no difference on statement 10 between those who prayed once a week and those who prayed daily. Eighty four percent of the students with 15 points prayed daily compared with those with 14 points $(76 \%)$. On the other hand $92 \%$ of the females $(n=24)$ prayed daily, so did $70 \%$ of the males. The highest percentage of those who prayed once a week, were found to be males at $18 \%$. All the students aged 21 years prayed daily followed by the 18 years group at $90 \%$; then 19 years at $80 \%$ and 20 years at $76 \%$. It is worth noting that the study was based on self-reporting and there is a tendency of respondents to under report. Social desirability bias can also not be ruled out. Perhaps those students who claimed to pray once were probably telling the truth compared to the rest as shown by behaviours they had not indulged in. Again the result in many ways resonates with Moring's study (1999) where 80\% of the Christian students admitted to cheating in high school and college.

\section{Conclusion and Recommendations}

The results of the study have shown that freshmen had a fairly good definition of what constituted cheating as captured in ten survey statements. However the most agreed form of cheating was copying another student's homework or assignments. Sitting close a friend during an examination was not considered cheating by most of the respondents. On the face value it is not cheating but what would be the motivation to sit close to a friend in an examination. This brings to the fore the argument that what constitutes cheating is dependent on one's perspective (McCabe, 2005; McCabe and Trevino, 1993). It is therefore not surprising that $40.7 \%$ of all the respondents admitted to having done this. Cheating behaviour is increased where students perceive certain behaviours as not cheating (Partello, 1993; Rodabaugh, 1996). Even given the good level of what academic dishonesty is by freshmen there is still need for institutions of higher learning to include and clearly define academic dishonesty in their ordinances. The department and the university in question should come up with clear definitions and policies to curb academic dishonesty (Klein et al., 2007). Indeed as observed by McCabe and Trevino (1996) students are unlikely to cheat where they are aware of the institutions policies on academic dishonesty.

At the university in question, during sessional examinations the problem of friends sitting close together is minimised by having the students sit in alphabetical order. However where students are not registered they 
are likely to sit anywhere as there would be no printed examination slips with their names. The forced sitting arrangement is also defeated were students come in late into the examination venue or purport not to have seen their attendance slips. The sitting space between candidates in examinations is also a factor, more space in between reducing the incidence of cheating. The university in question has inadequate facilities with most build before independence to cater for a very small student population. With freshmen showing this propensity it is imperative that faculty puts in place pre-emptive measures and minimise giving intrasessional examinations were students sit freely. It would be worthwhile to have students sit close to those sitting for a different paper. For instance Row A will have students sitting for say Management, followed by Row B sitting for Introductory Financial Accounting, then Row C say Corporate Finance and the order is repeated from row D onwards. Such a sitting arrangement though cumbersome can be done for both sessional and intra-sessional examinations. Caution should be however exercised on the examination duration the staggering should be ideally for papers with the same duration. In addition care should be taken not to mix answer sheets from different papers. Decreasing the invigilator student ratio would also assist as well as maintaining a gender balance in the examination venue. It is conceded that there are already other measures already in place and the study recommendations are meant to buttress such.

Male freshmen were found to be more relaxed in their definition of what constitutes cheating compared to females. In seven out of the ten statements more male students had cheated compared to females. This finding is in agreement with other studies that have found male students cheated more than females (Anderson, 1957; Baird, 1980; Ameen et al., 1996; Al-Qaisy, 2008). While all the respondents were Christians, the ratio of female students that prayed daily was relatively high compared to males $(92 \%$ and $70 \%)$. This finding may be explained by prior research indicating that higher levels of religiosity are associated with stronger ethical attitudes (Conroy and Emerson, 2004; Smith and Oakley, 1996). It must however be emphasized that the studies referred to above did not measure religiosity on gender lines. In the current study the suggestion is that females in the sample reported less cheating compared to males probably because they were more religious than them. The majority of freshmen admitted into the accounting programme at the university were males. While there is very little or nothing public universities can do on gender and religiosity faculty should be on guard and maintain a gender balance in say group assignments.

As reported earlier on freshmen with 14 points or less were found to have cheated more times in eight out of the ten statements compared to those with 15 points. Zastro $(1970: 157)$ in a review of five studies concerning undergraduate students concluded "cheating is less prevalent among students with high grades," a finding which is mirrored in the current study. Students whose academic performance is low have been found to cheat more compared to high performers (Crown and Spiller, 1998; Klein et al., 2007; Baird, 1980). In the current study 15 female students (47\%) and 17 male students (53\%) had 14 points. Freshmen with 14 points prayed daily less compared to those with 15 points. This finding is consistent with Bloodgood et al. (2010) were they found that highly intelligent individuals displayed less cheating if they were also highly religious. These results may be indicative of a gap in knowledge which needs to be filled that of academic performance versus gender and religiosity.

The most egregious behaviours freshmen had engaged in were: allowing another student to copy one's homework or assignment (51\%); collaborating on individual assignments (44.1); copying another student's homework or assignments (30.5\%); and sitting close to a friend during examinations (40.7\%). Klein et al. (2007) also found that copying or allowing another to copy as well as collaborating on assignments were the most common cheating behaviours. These figures may be the tip of an iceberg considering that the probability of under-reporting in self reporting studies can be as high as $83 \%$ with a low of $39 \%$ ( Sheers and Dayton, ) This can also be confirmed by the difference between those who admitted copying other students' homework or assignments and those who allowed the same. Copying and being copied is often a reciprocal exchange and there is every possibility that those who allowed copying also copied. The prevalence of the behaviours above prior to university instruction has several implications. First and foremost when faculty give assignments the feedback they get may not be reflective of the student's own performance. This fact is further compounded if the assignments contribute towards coursework thus threatening "scholarship as well as the validity of academic performance" (Oakley, 2011:46). This also means the cheater being is a "free rider and therefore gets higher marks than he or she deserves" (Magnus et al., 2002:125). It must be emphasised 
that even when students should work individually on assignments or homework they still collaborate and work together (McCabe and Cole, 1995).

Another fact is that the freshmen in this study had probably engaged in the said behaviours at high school where admittedly there is less pressure. At high school students only sit for two major examinations: Ordinary Level after 4 years of study and Advanced Level after 2 years of study. There is likely to be more pressure on the students at university considering that they have two examination sessions every academic year. This pressure and any other factor which may serve as a handicap will invariably "produce dishonest behaviour" in the student (Parr, 1936). Faculty are therefore advised to reduce as much as possible the weighting on assignments contributing towards coursework and give more tests and exercises under examination conditions. This is a plausible recommendation but it poses a few challenges in public universities particularly in Zimbabwe where a programme may have over 300 students and the teaching load per lecture is 3 classes (that is about 900 students) often without a teaching assistant. Qualitative courses can make use of anti-plagiarism software in checking for other forms of academic dishonesty but this is not easy with courses like accounting. It is not easy for faculty to detect most of the cheating behaviours and thus the need "for faculty to be very explicit about their policies regarding outside-classroom work and academic honesty" (Klein et al., 2007:204). While the number of students that admitted to finding what is on the examination and telling another student the same was low such behaviours were likely to be common at university level as in Klein et al. study (2007). There was a high likelihood of students assisting one another in an examination (Jendreck, 1992). To this end therefore faculty should desist from recycling examinations, tests, assignments, etc. Universities need a clear policy on the issue of recycling examinations with some suggesting a minimum period of three years.

The current study has shown that accounting freshmen had academic dishonesty ingrain ed in them prior to any university instruction. Further studies on freshmen in various disciplines may help to shade more light on whether accounting students are indeed different from the other groups. Research has also shown that other situational factors have a bearing on academic dishonesty such, writing a tough examination in a small room, lack of adequate supervision or invigilation (Baird, 1980). Thus it is imperative when considering the number of students to enrol to consider the facilities available and their capacity. Even where facilities permit large classes have been found to increase the incidence of cheating (Nowell and Laufer, 1997). One intervention to large classes has been the use of teaching assistants but caution still needs to be exercised. Magnus et al. (2002) found that students taught by teaching assistants were $32 \%$ more likely to cheat than students taught by faculty.

The results of this study should be considered in light of several factors. First and foremost the study used the self-reporting approach which is the most common approach and has been shown to provide reasonably accurate estimates (Cizek, 1999). Students may either under or over-report depending on their experiences (Whitley, 1998; Williams and Paulhus, 2004). Reliability is also a problem in self -reporting surveys and academic dishonesty under- reporting varies between 39\% and $83 \%$ of students' surveyed (Scheers and Dayton, 1987). What this may mean is that reported levels or extent of academic dishonesty may be worse than or higher than survey results obtained at any particular point in time. The focus of the study was to highlight that accounting freshmen come to university already initiated into the rites of cheating or academic dishonesty as it were. Research is required on whether university education reduces or increases their propensity to engage in unethical practices.

\section{References}

Adeniyi, E. O. \& Taiwo, S. A. (2011). A study of incidence and prevalence of academic dishonesty among Nigerian College of Education Students. European Journal of Humanities and Social Sciences, 4(2) (Special issue).

Anderson, W. (1957). Attitudes of university students toward cheating. Journal of Educational Research, 50, 581-588.

Allmon, D. E., Page, D. \& Roberts, R. (2000). Determinants of perceptions of cheating: Ethical orientation, personality, and demographics. Journal of Business Ethics, 23, 411-422. 
Al-Qaisy, L. M. (2008). Students' attitudes toward cheat [sic] and relation to demographic factors. European Journal of Social Sciences, 7(1), 140-146.

Ameen, E. C., Guffey, D. M. \& McMillan, J. J. (1996).Gender differences in determining the ethical sensitivity of future accounting professionals. Journal of Business Ethics, 15, 591-597.

Armstrong, M. B. (1987). Moral Development and Accounting Education. Journal of Accounting Education, (Spring), 27-43. doi: 10.1016/0748-5751(87)90036-4.

Baird, J. S. (1980). Current patterns in college cheating. Psychology in the Schools, 17, 515-522.

Barnett, T., Bass, K. \& Brown, G. (1996).Religiosity Ethical Ideology, and Intentions to Report a Peer's Wrongdoing. Journal of Business Ethics, 15, 1161-1174

Beltramini, R. F., Peterson, R. A. \& Kozmetsky, G. (1984). Concerns of college Students regarding business ethics. Journal of Business Ethics, 3(3), 195-200.

Bloodgood, J. M., Turnley, W. H. \& Mudrack, P. E. (2010). Ethics Instruction and the Perceived Acceptability of Cheating. Journal of Business ethics, 95(1), 23-37.

Borkowski, S. \& Ugras, Y. (1998). Business Students and Ethics: A Meta- Analysis. Journal of Business Ethics, $17,1117-1127$

Bowers, W. J. (1964). Student dishonesty and its control in college. Cooperative Research Project No.: OE 1672, New York: Columbia University, Bureau of Applied Social Research, Columbia University.

Brownell, H. C. (1928). Mental test traits of college cribbers. School and Society, 27, 764. CIA World Factbook, (2011). www.indexmundi.com>zimbabwe>demographics

Cizek, G. J. (1999). Cheating on tests: How to do it, detect it, and prevent it. Mahwah, NJ: Erlbaum.

Coffin, B. (2003). Breaking the Silence on White Collar Crime. Risk Management, 50(9), 8.

Conroy, S. J. \& Emerson, T. L. N. (2004). Business Ethics and Religion: Religiosity as a Predictor of Ethical Awareness among Students. Journal of Business Ethics, 50(4), 383-396

Cox, T. (2009). Study: Business students cheat more often than others. The Badger Herald.

Crown, D. F. \& Spiller, M. S. (1998). Learning from the Literature on Collegiate Cheating: A Review of Empirical Research. Journal of Business Ethics, 17, 683700

Eskridge, C. \& Ames, G. (1993). Attitudes about cheating and self-reported cheating behaviours of criminal justice majors and noncriminal justice majors: a research note. Journal of Criminal Justice Education, 4(1), 136-149.

Ford, R. C. \& Richardson, W. D. (1994). Ethical decision making: A review of the empirical literature. Journal of business ethics, 13(30), 205-221

Franklyn-Stokes, A. \& Newstead, S. E. (1995). Undergraduate cheating: Who does what and why? Studies in Higher Education, 20(2), 159-172.

Hetherington, E. M. \& Feldman, S. E. (1964). College cheating as a function of subject and situational variables. Journal of Educational Psychology, 55(4), 212-218.

Houston, J. P. (1986).Classroom Answer Copying: Role of Acquaintanceship and Free Versus Assigned Seating. Journal of Educational Psychology, 78, 230-232.

Iyer, R. \& Eastman, J. K. (2006). Academic dishonesty: Are business students from other college students? Journal of Education for Business, 3, 101-110.

Jeffrey, C. (1993). Ethical development of Accounting Students, Non-Accounting Business Students, and Liberal Arts Students. Issues in Accounting Education, 8(1), 86-96

Jendrek, M. P. (1992). Students' reactions to academic dishonesty. Journal of College Student Development, 33(3), 260-273.

Johnson, C. D. \& Gormly, J. (1972). Academic cheating: The contribution of sex, personality, and situational variables. Developmental Psychology, 6, 320-325.

Kerkvliet, J. \& Sigmund C. L. (1999).Can we control cheating in the classroom? Journal of Economic Education, 30, 331-43.

Kibler, W. \& Paterson, B. (1988).Strategies to prevent academic dishonesty. In W. L.Kibler, E. M. Nuss, B. G. Paterson, \& G. Pavela (Eds.), Academic integrity and student development: Legal issues, policy perspectives. Asheville, NC: College Administration Publications.

Klein, H. A., Levenburg, N. H., McKendall, M. \& Mothersell, W. (2007). Cheating during the college years: How do business students compare? Journal of Business Ethics, 72(2), 197-206.

Koenig, H. G. (1997). The effects of religion on physical and mental health. Binghamton, NY: The Haworth Pastoral Press. 
Koenig, H. G., Parkerson, G. R. \& Meador, K. G. (1997). Religion index for psychiatric research. American Journal of Psychiatry, 153, 885-886.

Kohlberg, L. (1981).The Philosophy of Moral Development: Moral Stages and the Idea of Justice Harper \& Row, San Francisco.

KPMG, (2012). Africa Fraud Barometer

Lampe, J. C. \& Finn, D. W. (1992) A Model of Auditors' Ethical Decision Processes. Auditing: A Journal of Practice and Theory, 11, 33-59.

Lampe, J. C. \& Finn, D. W. (1994) Teaching Ethic in Accounting Curricula. Business and Professional Ethics Journal, 13(1\&2), 89-128.

Lawson, R. A. (2004). Is classroom cheating related to business student propensity to cheat in the real world? Journal of Business Ethics, 49, 189-199

Lupton, R. A., Chapman, K. J. \& Weiss, J. E. (2000). A cross national exploration of business students' attitudes, perceptions, and tendencies toward academic dishonesty. Journal of Education for Business, 75(4), 231-235.

Lupton, R. A. \& Chapman, K. J. (2002). Russian and American college students' attitudes, perceptions, and tendencies towards cheating. Educational Research, 44(1), 17-22.

Magnus, J. R., Polterovich, V. M., Danilov, D. L. \& Savvteev, A.V. (2002). Tolerance of Cheating: An Analysis Across Countries. Journal of Economic Education, 3, 125-135.

Marsh, B. (2007). Plagiarism: Alchemy and remedy in higher education. Albany, NY: State University of New York Press.

McCabe, D. L. \& Trevino, L. K. (1993). Academic Dishonesty: Honour Codes and Other Contextual Influences. The Journal of Higher Education, 6(5), 522-538.

McCabe, D. L. \& Cole, S. (1995). Student Collaboration: Not always what the instructor wants. AAHE Bulletin, 3-6.

McCabe, D. L. \& Trevino, L. K. (1995). Cheating Among Business Students: A Challenge for Business Leaders and Educators. Journal of Management Education, 19(2), 205-218.

McCabe, D. L. \& Trevino, L. K. (1996). What we know about cheating in college: Longitudinal trends and recent development. Change, 28(1), 28-33.

McCabe, D. L. \& Trevino, L. K. (1997). Individual and Contextual Influence on Academic Dishonesty: A Multicampus Investigation. Research in Higher Education, 38(3), 379-396.

McCabe, D. L. (2005). It takes a village: Academic dishonesty and educational opportunity. Liberal Education, $9(3 / 4), 26-31$.

Michaels, J. W. \& Miethe, T. D. (1989). Applying theories of deviance to academic cheating. Social Science Quarterly, 70, 870-885.

Midlands State University- The Rules of Student Conduct and Discipline Ordinance, 2000, Ordinance No.2

Newstead, S. E., Franklyn-Stokes, A. \& Armstead, P. (1996). Individual differences in student cheating. Journal of Educational Psychology, 88(2), 229-241.

Nonis, S. \& Swift, C. O. (2001). An examination of the relationship between academic dishonesty and workplace dishonesty: A multi-campus investigation. Journal of Education for Business, 77(2), 69-76.

Nowell, C. \& Laufer, D. (1997). Undergraduate Student Cheating in the Fields of Business and Economies. Research in Economic Education, 18(1), 3-12.

Oakley, C. R. (2011).Instruction in ethics: Influences on undergraduate business students' academic dishonesty, unpublished doctoral dissertation, Colorado State University

Parr, F. W. (1936).The problem of student honesty. Journal of Higher Education, 7(6), 318-326.

Partello, P. (1993). First-year students and cheating: A study at Keene State College. Research Strategies, 11(3), 174-179.

Peacock, J. R. \& Poloma, M. M. (1988).Religiosity and life satisfaction across the Life course. Social Indicators Research, 48, 321-345.

Ponemon, L. (1992). Ethical Reasoning and Selection-Socialization in Accounting. Accounting, Organisations and Society, 17, 239-258.

Ponemon, L. \& Glazer, A. (1990).Accounting Education and Ethical Development: The Influence of Liberal learning on Students and Alumni in Accounting Practice. Issues in Accounting Education, 5(2), 195 208

Rest, J. R. (1986). Moral development: Advances in research and theory. New York, NY: Praeger. 
Robertson, L. A. (2008).A comparison of Christian and state institution of higher education: The relationship between religiosity and academic dishonesty among athletes, unpublished doctoral dissertation Liberty University

Rodabaugh, R. C. (1996). Institutional commitment to fairness in college teaching. In Fisch, L. (Ed.), Ethical dimensions of college and university teaching: Understanding and honouring the special relationship between teachers and students (pp.37-45). San Francisco, CA: Jossey-Bass.

Rowatt, W. \& Kirkpatrick, L. A. (2002). Two Dimensions of Attachment to God and Their Relation to Affect, Religiosity, and Personality Constructs. Journal for the scientific Study of Religion, 41(4), 637-651.

Scanlon, P. (2006). Solving the problem of Internet plagiarism? The technological expediency of online plagiarism-checkers. Teachers College Record. Retrieved from http://www.tcrecord.org/PrintContent.asp?ContentID=12797

Scheers, N. J. \& Dayton, C. M. (1987). Improved estimation of academic cheating behaviour using the randomized response technique. Research in Higher Education, 26, 61-69.

Shaub, M. K. (1994). An Analysis of the Association of Traditional Demographic Variables with the Moral Reasoning of Auditing Students and Auditors. Journal of Accounting Education, 12(1), 1-26.

Sims, R. L. (1993). The Relationship between Academic Dishonesty and Unethical Business Practices. Journal of Education of Business, 68(4), 207-211.

Singhal, A. C. (1982). Factors in Students' Dishonesty. Psychological Reports, 51,775-780

Smith, P. L. \& Oakley, E. F. (1996). The value of ethics education in business school curriculum. College Student Journal, 30, 274-283.

St. Pierre, K. E., Nelson, E. S. \& Gabbin, A. L. (1990). A Study of the Ethical Development of Accounting Majors in Relation to Other Business and Non business Disciplines. The Accounting Educators' Journal, 3, 2335

Sweeney, J. T. (1995). The Moral Expertise of Auditors: An Explanatory Analysis. Research on Accounting Ethics, 1, 213-234

University of Zimbabwe Act.The Rules of Student Conduct and Discipline Ordinance 1984, Ordinance No.30

Whitley, B. E. (1998). Factors associated with cheating among college students: A review. Research in Higher Education, 39(3), 235-274.

Williams, K. M. \& Paulhus, D. L. (2004). Factor Structure of the Self-report Psychopathy Scale (SRP-II) in Forensic Samples. Personality and Individual Differences, 37, 765-778.

Wilkinson, R. \& Pickett, K. (2009). The Spirit Level: Why More Equal Societies Almost Always Do Better. The Equality Trust

Zastrow, C. (1970). Cheating Among College Graduate Students. Journal of Educational Research, 64(4), 157160. 